\title{
Antioxidant and Cholinesterase Inhibitory Activities of Aqueous Extract from Rainbow Trout Oncorhynchus mykiss
}

\author{
Jae-Min Baek ${ }^{1}$, Na Young Yoon ${ }^{2 *}$, Yeon-Kye Kim², Doo-Seog Lee ${ }^{2}$, \\ Ho-Dong Yoon ${ }^{2}$ and Jeung-Sook Park ${ }^{1}$ \\ ${ }^{1}$ Central Regional Inland Fisheries Research, National Fisheries Research \& \\ Development Institute, Gapyeong 477-815, Korea \\ ${ }^{2}$ Food and Safety Division, National Fisheries Research \& Development Institute, \\ Busan 617-705, Korea
}

\begin{abstract}
We investigated the antioxidant and cholinesterase inhibitory activities of the aqueous extract of rainbow trout Oncorhynchus mykiss. The antioxidant activity of $O$. mykiss aqueous extract was determined by in vitro peroxynitrite scavenging activity and reducing power assays. The aqueous extract of $O$. mykiss showed potent peroxynitrite radical scavenging activity $\left(\mathrm{IC}_{50}=0.12 \pm 0.001\right.$ $\mathrm{mg} / \mathrm{mL}$ ) and reducing power (absorbance $=0.47 \pm 0.001$ ) at the concentration of $1 \mathrm{mg} / \mathrm{mL}$. The in vitro cholinesterase inhibitory activity of $O$. mykiss aqueous extract was examined using spectrophotometric analyses of acetyl- and butyrylcholinesterase. The aqueous extract of $O$. mykiss showed acetylcholinesterase inhibitory activity $\left(\mathrm{IC}_{50}=1.61 \pm 0.13 \mathrm{mg} / \mathrm{mL}\right)$, but did not exhibit inhibitory activity against butyrylcholinesterase. These results suggest that $O$. mykiss possesses antioxidant and acetylcholinesterase inhibitory activities and provide scientific evidence for the health benefits of $O$. mykiss aqueous extract.
\end{abstract}

Key words: Oncorhynchus mykiss, Rainbow trout, Antioxidant, Cholinesterase

\section{Introduction}

The overproduction of free radical species causes oxidative stress that contributes to cellular aging and neuronal damage, and it is associated with chronic degenerative diseases, including Alzheimer's disease (AD) (Sastre et al., 2000). AD, a progressive neurodegenerative disorder that is commonly seen in elderly individuals, is characterized by memory and cognitive ability loss, behavior disturbances, and personality changes (Bachman et al., 1992). The etiology of $\mathrm{AD}$ remains unclear; one of the most convincing theories is the cholinergic hypothesis, which implicates a deficiency in neurotransmitters, such as acetylcholine (ACh) and butyrylcholine (BCh) (Schneider, 2001). Efforts to prevent AD have focused on the activation of cholinergic functions through the inhibition of cholinesterase (ChE), which hydrolyzes the cholinergic neuromediators and reduces oxidative stress (Schneider, 2001).

(c) This is an Open Access article distributed under the terms of the Creative Commons Attribution Non-Commercial License (http://creativecommons.org/licenses/by-nc/3.0/) which permits unrestricted non-commercial use, distribution, and reproduction in any medium, provided the original work is properly cited.
Oncorhynchus mykiss belongs to the Salmonidae family of North American cold-water fish (Behnke, 1992). O. mykiss extracts have been reported to have potential health benefits, such as 3-hydroxy-3methylglutaryl coenzyme A reductase expression reduction and antimutagenic effects (Oh et al., 2008, 2009).

In the present study, the antioxidant and $\mathrm{ChE}$ inhibitory activities of $O$. mykiss aqueous extract were investigated in vitro by evaluating its ability to scavenge peroxynitrite anions $\left(\mathrm{ONOO}^{-}\right)$, its reducing power, and its inhibitory activity against acetyl$(\mathrm{AChE})$ and butyrylcholinesterase (BChE).

\section{Materials and Methods}

\section{Materials}

O. mykiss (average total length: $40-50 \mathrm{~cm}$ ) were collected in May 2010 at Sangju City, Gyeongbuk, South Korea. Samples were prepared by removing the heads, fins, bones, and internal organs of the fish and obtaining extract in five times the volume of distilled water at $100^{\circ} \mathrm{C}$ for $3 \mathrm{~h}$. After evaporating,

\footnotetext{
*Corresponding author: dbssud@nfrdi.go.kr

Copyright@The Korean Society of Fisheries and Aquatic Science
} 
the extract was freeze-dried.

\section{Reducing power assay}

Reducing power was evaluated by the method of Oyaizu (1986). Various concentrations of samples $(2.5 \mathrm{~mL}$ ) were mixed with $2.5 \mathrm{~mL}$ of $200 \mathrm{mM}$ sodium phosphate buffer (pH 6.6) and $2.5 \mathrm{~mL}$ of $1 \%$ potassium ferricyanide. After incubation at $50^{\circ} \mathrm{C}$ for $20 \mathrm{~min}, 2.5 \mathrm{~mL}$ of $10 \%$ trichloroacetic acid $(\mathrm{w} / \mathrm{v})$ was added. The mixture was centrifuged at $2,000 \mathrm{~g}$ for 10 min, and $5 \mathrm{~mL}$ of the upper layer was mixed with deionized water and $1 \mathrm{~mL}$ of $0.1 \%$ ferric chloride. Absorbance was measured at $700 \mathrm{~nm}$ using a spectrophotometer (Powerwave XS; Bio-Tex, Inc., Houston, TX, USA). L-ascorbic acid was used as a positive control.

\section{Peroxynitrite scavenging activity}

$\mathrm{ONOO}^{-}$scavenging activity was measured by the method of Kooy et al. (1994) with minor modification. Each sample was mixed with rhodamine buffer ( $\mathrm{pH}$ 7.4) and $5 \mathrm{mM}$ dihydrorhodamine (DHR) 123. After incubation for $5 \mathrm{~min}$, the sample was treated with authentic $\mathrm{ONOO}^{-}$. The fluorescence intensity of the oxidized DHR 123 was measured with a microplate fluorescence reader (Wallac 1420; PerkinElmer, Waltham, MA, USA) at excitation and emission wavelengths of $485 \mathrm{~nm}$ and $530 \mathrm{~nm}$, respectively. L-ascorbic acid was used as a positive control.

\section{Cholinesterase inhibitory activity assay}

Inhibitory activity against $\mathrm{ChE}$ was measured using the spectrophotometric method developed by Ellman et al. (1961). The reaction mixture contained

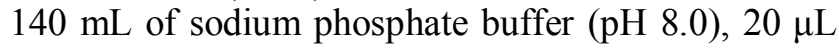
of sample, and $20 \mu \mathrm{L}$ of either AChE $(0.36 \mathrm{U} / \mathrm{mL})$ or $\operatorname{BChE}(0.36 \mathrm{U} / \mathrm{mL})$. The solution was placed in a $96-$ well microplate, mixed, and incubated at room temperature for $15 \mathrm{~min}$. After incubation, $10 \mu \mathrm{L}$ of
Ellman's reagent and $10 \mu \mathrm{L}$ of $\mathrm{ACh}$ or $\mathrm{BCh}$ were added. The absorbance of all reactions was measured using a spectrophotometer (Powerwave XS; Bio-Tex, Inc.). Eserine was used as a positive control.

\section{Proximate composition analysis}

The proximate composition analysis was performed using the methods described by the Association of Official Analytical Chemists (1995).

\section{Results and Discussion}

\section{Antioxidant activity}

Antioxidant properties are related to radical scavenging and reduction capacities. $\mathrm{ONOO}^{-}$is a strongly oxidizing and nitrating species that induces lipid peroxidation, thiol oxidation, and amino acid modification and causes DNA damage. $\mathrm{ONOO}^{-}$ overproduction may cause several neurological diseases, such as AD and Parkinson's disease (Squadrito and Pryor, 1998). Reduction is related to the donation of hydrogen atoms to ferric complexes and can disturb reactions between radicals (Singh and Rajini, 2004).

The antioxidant activity of $O$. mykiss aqueous extract was determined by evaluating $\mathrm{ONOO}^{-}$ scavenging activity and reducing power. Table 1 and Fig. 1 show the results of these analyses. O. mykiss aqueous extract exhibited potent $\mathrm{ONOO}^{-}$scavenging activity $\left(\mathrm{IC}_{50}=0.12 \pm 0.001 \mathrm{mg} / \mathrm{mL}\right)$ and considerable reducing power that increased in a dose-dependent manner (absorbance $=0.19 \pm 0.003, \quad 0.26 \pm 0.0001$, $0.30 \pm 0.004$, and $0.47 \pm 0.001$ at concentrations of 0.1 , $0.2,0.5$, and $1 \mathrm{mg} / \mathrm{mL}$, respectively). However, the $\mathrm{ONOO}^{-}$radical scavenging activity and reducing power of $O$. mykiss were lower than those of Lascorbic acid, which was used as a positive control.

According to Atif et al. (2006) and Oh et al. (2008), fish in the Salmonidae family contain small quantities

Table 1 . The peroxynitrite $\left(\mathrm{ONOO}^{-}\right)$scavenging and cholinesterase inhibitory activity of the aqueous extract of Oncorhynchus mykiss

\begin{tabular}{lccc}
\hline \multirow{2}{*}{ Samples } & \multicolumn{3}{c}{$\mathrm{IC}_{50}(\mathrm{mg} / \mathrm{mL})$} \\
\cline { 2 - 4 } & $\mathrm{ONOO}^{-}$ & $\mathrm{AChE}$ & $\mathrm{BChE}$ \\
\hline O. mykiss & $0.12 \pm 0.001$ & $1.61 \pm 0.13$ & $\mathrm{NE}$ \\
L-ascorbic acid & $0.00013 \pm 0.00007$ & $0.0025 \pm 0.0002$ & $0.0076 \pm 0.0003$ \\
Eserine & &
\end{tabular}

The values of $\mathrm{ONOO}^{-}$scavenging and cholinesterase (ChEs) inhibitory activities were expressed as the means \pm SD of $50 \%$ inhibitory concentrations of three experiments. L-ascorbic acid and eserine were used as positive controls of $\mathrm{ONOO}^{-}$scavenging and cholinesterase inhibitory activity assays, respectively.

AChE, acetylcholinesterase; $\mathrm{BChE}$, butyrylcholinesterase; NE, no effect. 


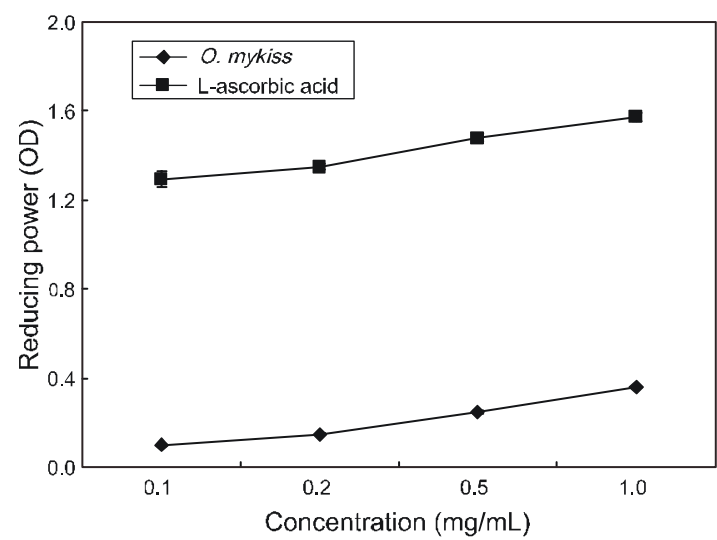

Fig. 1. The reducing power of the aqueous extract of Oncorhynchus mykiss.

of several bioactive constituents, including phenolic ingredients and metallothioneins, which have shown positive correlations with antioxidant activity. The antioxidant activities of $O$. mykiss aqueous extract may be due to the presence of these constituents.

\section{Cholinesterase inhibitory activities}

$\mathrm{ChE}$ inhibitors are recognized as the most promising therapeutic agents for $\mathrm{AD}$, and have been shown to affect cognitive and behavioral symptoms in clinical studies (Giacobini, 2004). AChE inhibitors increase the endogenous levels of $\mathrm{ACh}$ and cholinergic neurotransmission. $\mathrm{BChE}$ inhibitors decrease the accumulation of neural plaques in senile brains. Thus, the achievement of a balance between AChE and $\mathrm{BChE}$ inhibitors may increase the efficacy of treatment (Yu et al., 1999).

The ChE inhibitory activity of $O$. mykiss aqueous extract was evaluated by AChE and $\mathrm{BChE}$ inhibitory activity assays. Table 1 presents the results of these analyses. O. mykiss aqueous extract exhibited $\mathrm{AChE}$ inhibitory activity $\left(\mathrm{IC}_{50}=1.61 \pm 0.13 \mathrm{mg} / \mathrm{mL}\right)$ but showed no BChE inhibitory activity. This selective AChE inhibitory activity may be due to the binding properties between the enzyme and substrate (Silman and Sussman, 2005). AChE is a substrate-specific enzyme that exists in nerve synapses and can degrade only $\mathrm{ACh}$, whereas $\mathrm{BChE}$ is a nonspecific enzyme located in plasma and tissues (Silman and Sussman, 2005). As with antioxidant activities, the AChE inhibitory activity of $O$. mykiss aqueous extract was lower than that of eserine, which was used as a positive control.

\section{Proximate composition analysis}

The proximate composition of $O$. mykiss meat is shown in Table 2. The moisture, crude protein, crude
Table 2. The proximate composition of Oncorhynchus mykiss meat

\begin{tabular}{lc}
\hline Components & O. mykiss meat (\%) \\
\hline Moisture & $71.9 \pm 1.04$ \\
Crude protein & $20.8 \pm 0.78$ \\
Crude lipid & $4.5 \pm 0.28$ \\
Ash & $1.7 \pm 0.09$ \\
\hline
\end{tabular}

The values were expressed as the mean $\pm \operatorname{SD}(n=3)$.

lipid, and ash contents of O. mykiss meat were determined to be $71.9 \pm 1.04,20.8 \pm 0.78,4.5 \pm 0.28$, and $1.7 \pm 0.09 \%$ per $100 \mathrm{~g}$ of edible meat, respectively. The lipid components of $O$. mykiss meat contain bioactive constituents, including carotenoids and unsaturated fatty acids (Matsuno et al., 1980; Kim and Choi, 1993, Choi et al., 2010). Carotenoids, such as astaxanthin, zeaxanthin, canthaxanthin, diatoxanthin, and cryptoxanthin, and polyunsaturated fatty acids, including eicosapentaenoic acid and docosahexaenoic acid, are abundant in the integument and muscle of $O$. mykiss. These constituents have been reported to exhibit several beneficial bioactivities, including neuroprotective effects against neurotoxicity (Matsuno et al., 1980; Kim and Choi, 1993; Lim et al., 2005).

In conclusion, O. mykiss aqueous extract showed potent $\mathrm{AChE}$ inhibitory activity that may be related to its antioxidant properties. Further detailed investigations are necessary to isolate and identify the active constituents in the extract and to clarify the mechanism of their activity.

\section{Acknowledgments}

This work was funded by a grant from the National Fisheries Research \& Development Institute (NFRDI), Korea

\section{References}

Association of Official Analytical Chemists. 1995. Official Methods of Analysis. 16th ed. Association of Official Analytical Chemists, Washington, DC, US, pp. 49-59.

Atif F, Kaur M, Yousuf S and Raisuddin S. 2006. In vitro free radical scavenging activity of hepatic matallothionein induced in an Indian freshwater fish, Channa punctata Bloch. Chem Biol Interact 162, 172180.

Bachman DL, Wolf PA, Linn R, Knoefel JE, Cobb J, Belanger A, D'Agostino RB and White LR. 1992. Prevalence of dementia and probable senile dementia of the Alzheimer type in the Framingham study. 
Neurololgy 42, 115-119.

Behnke RJ. 1992. Native Trout of Western North America. American Fisheries Society Monograph 6, Bethesda, MD, US, pp. 1-275.

Choi CS, Eom SH, Lee MS and Kim YM. 2010. Effect of an astaxanthin-supplemented diet on the nutritional composition of rainbow trout (Oncorhynchus mykiss). Kor J Fish Aquat Sci 43, 109-116.

Ellman GL, Courtney KD, Andres V Jr and Featherstone RM. 1961. A new and rapid colorimetric determination of acetylcholinesterase activity. Biochem Pharmacol 7, 88-95.

Giacobini E. 2004. Drugs that target cholinesterase. In: Cognitive Enhancing Drugs. Buccafusco JJ, ed. Birkhauser-Verlag, Basel, CH, pp. 11-36.

Kim KS and Choi YJ. 1993. Food components of coho salmon and rainbowtrout. Korean J Food Nutr 6, 7380.

Kooy NW, Royall JA, Ischiropoulos H and Beckman JS. 1994. Peroxynitrite-mediate oxidation of dihydrorhodamine 123. Free Radic Biol Med 16, 146-156.

Lim GP, Calon F, Morihara T, Yang F, Teter B, Ubeda O, Salem N Jr, Frautschy SA and Cole GM. 2005. A diet enriched with omega-3 fatty acid docosahexaenoic acid reduces amyloid burden in an aged Alzheimer mouse model. J Neurosci 25, 3032-3240.

Matsuno T, Katsuyama M and Nagata S. 1980. Comparative biochemical studies of carotenoids in fishes-XIX, carotenoids of chum salmon, coho salmon, biwa trout, red-spotted masu salmon, masu salmon and kokanee. Bull Jpn Soc Sci Fish 46, 879884.

Oh HT, Kim SH, Choi HJ, Chung MJ and Ham SS. 2008. Antioxidative and antimutagenic activities of $70 \%$ ethanol extract from masou salmon (Oncorhynchus masou). Toxicol In Vitro 22, 1484-1488.

Oh HT, Chung MJ, Kim SH, Choi HJ and Ham SS. 2009. Masou salmon (Oncorhynchus masou) ethanol extract decreases 3-hydroxy-3-methylglutaryl coenzyme A reductase expression in diet-induced obese mice. Nutr Res 29, 123-129.

Oyaizu M. 1986. Studies on products of browning reaction: antioxidative activities of products of browning reaction prepared from glucosamine. Jpn J Nutr 44, 307-315.

Sastre J, Pallardó FV and Viña J. 2000. Mitochondrial oxidative stress plays a key role in aging and apoptosis. IUBMB Life 49, 427-435.

Schneider LS. 2001. Treatment of Alzheimer's disease with cholinesterase inhibitors. Clin Geriatr Med 17, 337-358.

Silman I and Sussman JL. 2005. Acetylcholinesterase: 'classical' and 'non-classical' functions and pharmacology. Curr Opin Pharmacol 5, 293-302.

Singh N and Rajini PS. 2004. Free radical scavenging activity of an aqueous extract of potato peel. Food Chem 85, 611-616.

Squadrito GL and Pryor WA. 1998. Oxidative chemistry of nitric oxide: the roles of superoxide, peroxynitrite, and carbon dioxide. Free Radic Biol Med 25, 392-403.

Yu Q, Holloway HW, Utsuki T, Brossi A and Greig NH. 1999. Synthesis of novel phenserine-based-selective inhibitors of butyrylcholinesterase for Alzheimer's disease. J Med Chem 42, 1855-1861.

(Received 18 November 2010; Revised 7 March 2011; Accepted 16 May 2011) 